\title{
Banksia croajingolensis (Proteaceae) a new species from East Gippsland, Victoria
}

\author{
W M Molyneux ${ }^{1}$ and S G Forrester ${ }^{2}$ \\ ${ }^{1}$ La Trobe University, Department of Botany, Life Sciences School, Bundoora 3076 Victoria, \\ Australia \\ ${ }^{2} 200$ Beachs Lane, Dixons Creek 3775 Victoria, Australia
}

\begin{abstract}
Banksia croajingolensis Molyneux \& Forrester is described and illustrated. Its relationships with Banksia integrifolia, Banksia marginata and Banksia paludosa are discussed.
\end{abstract}

\section{Introduction}

A new previously unrecorded species of Banksia was discovered by the authors in 2000 and identified at the time as Banksia paludosa. The new species is distinguished from Banksia integrifolia, Banksia marginata and B. paludosa, with which it shares certain character states. It is a narrow endemic apparently confined to one drainage line on a coastal heathland in Croajingolong National Park. It is sympatric on its margins with B. integrifolia and B. marginata but not with B. paludosa, which is not recorded for Victoria (Jeanes 1996). This latter species occurs in New South Wales (Harden 2002) with its southern limits on coastal heathlands and nearby forest sites about $35 \mathrm{~km}$ to the north-east of the new species. It is further separated from the new species by its position on the north side of the Howe Range and by the extensive Mallacoota Inlet lake system. This system has probably presented a barrier to the migration of plants such as Banksia since the last Ice Age. The authors did discover a small population of a dwarfed Banksia in June 2006 on an adjoining heathland to the north of the $B$. croajingolensis population which would appear to have some affinities to B. paludosa. Its regularly toothed leaf margin is a character shared with $B$. paludosa populations in southern NSW but not with adult foliage of B. croajingolensis, B. integrifolia or $B$. marginata. It may suggest either an earlier presence of $B$. paludosa in Victoria or a closer proximity which may have facilitated cross pollination.

\section{Taxonomy}

Banksia croajingolensis Molyneux \& Forrester sp. nov.

A B. paludosa R. Br. foliis integris plerumque obtusis interdum lobatis apicem versus, internodiis brevioribus, a $B$. integrifolia L. $\mathrm{f}$. habitu minore floribus in fructu persistentibus et seminibus ultra unum annum retentis, a $B$. marginata Cav. foliis nec 
semper emarginatis nec truncatis et floribus et infructescentiis minoribus differt. Ab omnibus speciebus indicatis processu florentis basipeto non acropeto differt.

Type: Victoria, Croajingolong National Park, south-western heathland above Shipwreck Creek, c 12 km south-west of Mallacoota, Molyneux \& Forrester s.n., 21 June.2006 (holo: MEL 2292847; iso: CANB, NSW)

A mostly small, rarely larger, spreading lignotuberous shrub propagating by sexual means and extending asexually by the production of ramets, 35-60 $(-100) \mathrm{cm}$ tall and $45-120 \mathrm{~cm}$ wide. Branchlets initially trigonous soon becoming rounded, either glabrous with yellow and red markings or lightly white or rusty pubescent and soon becoming glabrous, nodes crowded. Leaves verticillate, sub-verticillate or scattered (more commonly sub-verticillate), narrowly obovate, obtuse, entire or seldom irregularly notched towards apex, shortly apiculate or emarginate, 16-60 mm long, 5-17 mm wide, glabrous above or with early scattered hairs, shiny, primary nerves evident, mid-vein recessed, undersurface appearing white-tomentose, with evident nerves and reticulum; nerves occasionally lightly woolly, mid vein glabrous or less often with a light ferruginous indumentum, margins recurved. Juvenile ramets glabrous, stems angular, leaves obovate-cuneate, truncate, emarginate or obtuse, irregularly toothed, sub-verticillate or scattered, 12-55 mm long, 6-8 $\mathrm{mm}$ wide. Conflorescences cylindrical, terminal or from older wood within canopy, 70-140 mm long, 42-55 mm wide at flowering, basipetalous, shortly pedunculate, basal bracts linear-subulate, ferruginous-tomentose in c. three rows mostly $3(-5) \mathrm{mm}$ long, common bracts \pm rhomboidal, white-tomentose or lightly silky-ferruginous, 1.8-2.1 $\mathrm{mm}$ across. Flowers openly spaced mostly at $90^{\circ}$ to rachis, yellow with grey-brown, grey-green or golden pubescence, perianth 15-18 mm long including limb of $3.5 \mathrm{~mm}$ perianth c. $0.5 \mathrm{~mm}$ wide, tepals twisting, spreading to base, limb acute, pistil slender, glabrous $15-26 \mathrm{~mm}$ long including style end, straight or bowed sharply just before anthesis, ovary c. $0.8 \mathrm{~mm}$ long with few villous hairs at base, style end not thickened c. $1.5 \mathrm{~mm}$ long, about same width as style; spent styles variously at $90^{\circ}$ to rachis, straight or relaxed at $70-80^{\circ}$ to rachis; old flowers retained for several years. Infructescences $90-120 \mathrm{~mm}$ long, 35-38 mm wide, follicles elliptical 13-19 $\mathrm{mm}$ long, 3-5 mm high, (4-)5-6(-8) mm wide, Seed obovate-cuneate, $8-10 \mathrm{~mm}$ long, 3-3.5 mm wide, wing $11-12 \mathrm{~mm}$ high, $12-13 \mathrm{~mm}$ wide. (Fig. 1).

\section{Recommended vernacular: Gippsland Banksia}

Distribution: apparently endemic to East Gippsland, Victoria, where confined to a single short drainage line draining north from a coastal heathland elevated above the south bank of Shipwreck Creek, c. $12 \mathrm{~km}$ SW of Mallacoota. The population of about 480 individuals is confined within the following coordinates: $37^{\circ} 38^{\prime} 98^{\prime \prime S}, 149^{\circ} 41^{\prime} 63^{\prime \prime} \mathrm{E}$ (on its southern boundary); 37 $38^{\prime} 95^{\prime \prime S}, 1^{\circ} 41^{\prime} 70^{\prime E}$ (on its northern boundary);

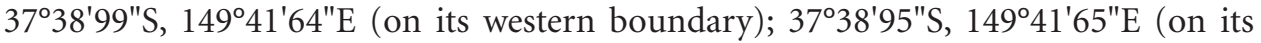
eastern boundary).

Habitat: Banksia croajingolensis is emergent from mixed coastal heathland vegetation in moist sandy soils associated with Acacia suaveolens, Allocasuarina paludosa, Babingtonia pluriflora, Epacris impressa, Hakea teretifolia, Patersonia occidentalis, Persoonia laevis, Xanthorrhoea resinosa and various sedges and rushes. Both B. integrifolia and B. marginata are sympatric on the margins of the B. croajingolensis stand. Banksia marginata tends to be a sub-shrub within or just emerging from the dense heathland canopy on the eastern margins of the stand whereas B. croajingolensis is always emergent. It is strongly 


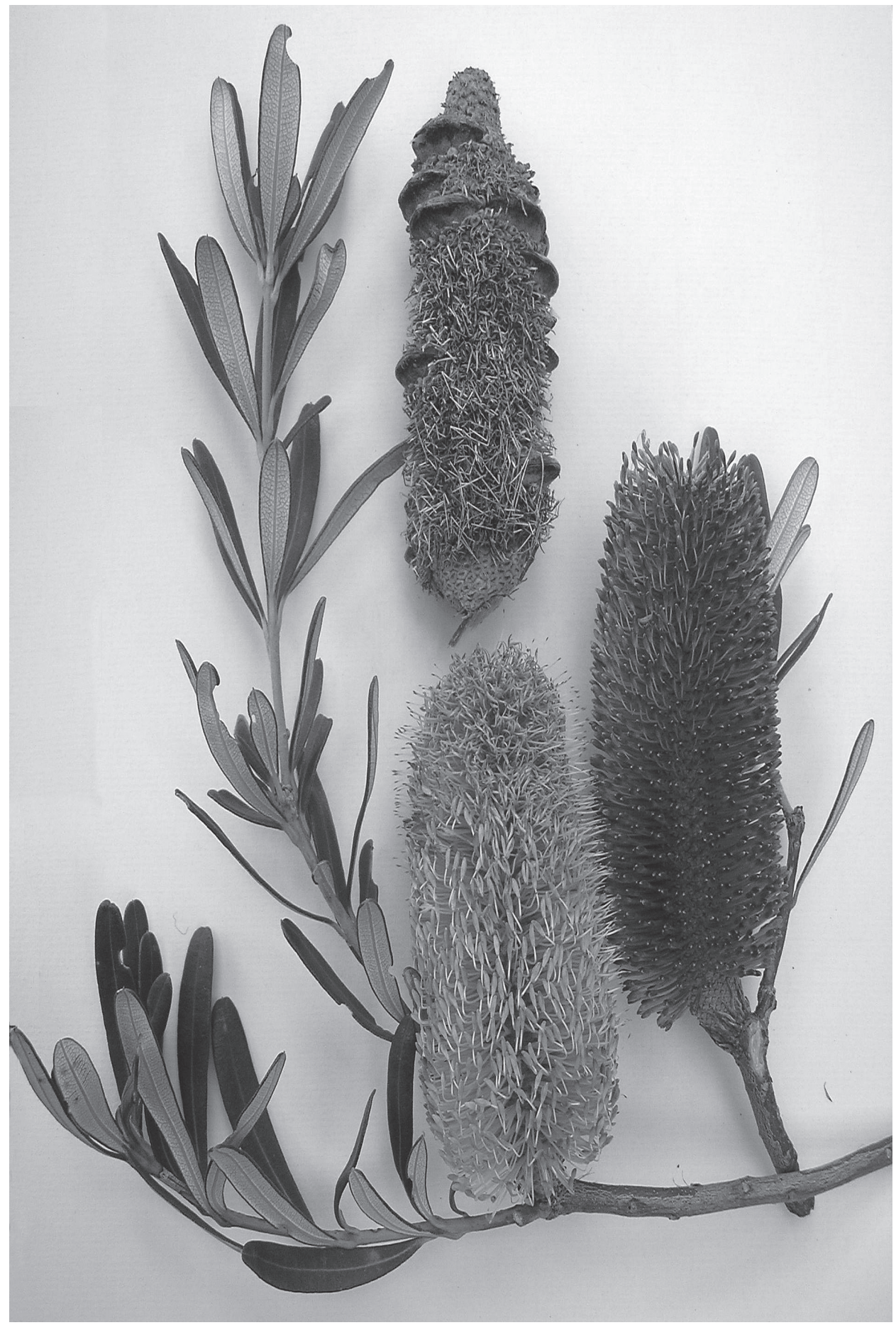

Fig. 1. Banksia croajingolensis illustrating variation in bud colour, basipetalous flowering sequence, the mostly sub-verticellate leaf arrangement, evident nerves and reticulum on lower leaf surface, and mature infructescences with retained seed. 
sympatric with $B$. integrifolia on its western margins and on the edges of woodland containing Banksia serrata, Eucalyptus sieberi and an undescribed eucalypt with affinity to E. globoidea. On its northern boundary it is sympatric with apparent hybrid swarms including $B$. integrifolia and an unknown second parent.

The underlying geology is strongly banded and distorted mudstone and slates of Ordovician origin.

Etymology: the specific epithet commemorates the Gunai/Kurnai Nation name for the region from which the species is currently known. The original name Krowathunkoolong was adapted in the early days of European settlement to Croajingolong, the name of the county to which the new species is apparently endemic. The epithet 'croajingolensis' is a euphonic contraction of the less appealing 'croajingolongensis' as suggested by Johnson and Hill (1990) when they described Eucalyptus croajingolensis.

Conservation Status: using the IUCN Red List Categories and criteria (IUCN 2001), the new species is assessed as Vulnerable with a conservation code of VU D1+2 on account of its small population size, very restricted area of occupancy and restriction to a single location.

Representative specimens examined: Victoria: Croajingolong National Park, above Shipwreck Creek, [ca. 12 km SW of Mallacoota], Molyneux \& Forrester, 24 Aug 2005 (MEL 2292848, MEL 2292849, MEL 2292856); ibid., 17 vi 2006, (MEL 2292860, MEL 2288265).

\section{Discussion}

The new species differs from $B$. paludosa in having entire mostly obtuse leaves with occasional lobing toward the apex, and much shorter leaf internodes; from $B$. integrifolia which is a large shrub or small tree which sheds its flowers following anthesis and with seed dehiscing usually within one year; and from $B$. marginata which has consistently truncate and often emarginate leaves, and much smaller flowers and generally much smaller conflorescences and infructescences.

It differs from all of the above three species in being basipetalous, not acropetalous, in its flowering sequence. This difference in flowering sequence raises questions as to the classification of B. croajingolensis within Banksia. In all states other than flowering sequence, it nests within section Banksia of subgenus Banksia (species with straight style ends). This sequence is common in the eastern species B. ericifolia and the B. spinulosa group and a number of Western Australian species in series Spicigerae of section Oncostylis and with Banksia quercifolia and Banksia oreophila which form series Quercinae of section Banksia. When considering the basipetaous sequence of flowering in B. croajingolensis compared with other species in section Banksia, it may be necessary to consider also whether a basipetal sequence implies a broader relationship to other taxa sharing this feature. As this flowering sequence is shared across different series and sections of subgenus Banksia across southern Australia, it is possible that they arose spontaneously and independently of other groups' genetic input.

The flowering sequence anomaly in B. croajingolensis compared with other members of series Banksiae of section Banksia, with which it otherwise shares many character states, may require it to be recognized in a new series. 
The table of comparison with B. croajingolensis (Table 1) includes close regional forms of B. integrifolia and B. marginata and southern New South Wales forms of B. paludosa from similar coastal or near coastal localities. These are all members of Banksia series Banksiae. Whilst $B$. integrifolia and B. marginata are sympatric with the new species, the $B$. paludosa collections used for comparison are from heathland and woodland populations in Nadgee Nature Reserve and Green Cape in south-eastern New South Wales. Banksia serrata was not included as a comparator as it is a member of Banksia series Orthostylis [and apparently not implicated in the ancestry of B. croajingolensis]. It would appear from both physical observations and morphometric measurements that B. integrifolia, B. marginata and B. paludosa have influenced the development of $B$. croajingolensis and that this species may have resulted from various crossings and back crossings between them. In seedling trials conducted from 2006 to 2007, there was no apparent segregation in the offspring of $B$. croajingolensis. It is genetically segregated from the other three species because it is self perpetuating and clonal, and forms a substantial population. This cannot be said of the other three species as it can be demonstrated that there is clear hybridization between all of them, which has resulted in long standing confusion regarding the identity of certain specimens.

Over approximately eight years of field study on the banksias of south-eastern NSW and far eastern Victoria from Green Cape in NSW to Shipwreck Creek and Sandpatch heathlands in Victoria, the authors have noted a number of these apparent hybrid swarms.

In 1972 one of us (WMM) collected seed of a 'robust' B. paludosa among typical specimens on the middle south-west slopes of Green Cape. The few progeny which resulted from their germination appeared to share characters of B. paludosa and B. integrifolia, which are closely related.

In 2004 the authors discovered a small population of a large spreading banksia up to $\pm 2 \mathrm{~m}$ tall on the lower south-west slopes of Green Cape. This small stand grew sympatrically with both dwarfed B. paludosa and small tree forms of B. integrifolia.

Investigations of major characters such as branchlet indumentum, leaf undersurface indumentum, flower colour, the degree of spent flower retention and of long or short term seed retention, indicated that these stands should be regarded as hybrids between the two species.

During field work at Impressa Moor in Nadgee Nature Reserve with Head Ranger Lyn Bell, we found distinct variations in specimens which we had at first thought were either B paludosa or B. marginata. We recorded character states in these plants which appeared to be intermediate between these two species. Some of these are not unlike the small population with affinities to $B$. paludosa which the authors collected in June 2006 on the northern heathland above Shipwreck Creek (about 50 plants $\pm 35 \mathrm{~cm}$ tall $\mathrm{x}$ $40 \mathrm{~cm}$ wide). The Impressa Moor population was growing sympatrically with the local small heathland form of B. marginata.

In the region south west of Mallacoota putative hybrid swarms between $B$. integrifolia and B. marginata are not uncommon. Large but rounded B. integrifolia-like plants coexist with more typical upright narrow forms, but while the latter shed old flowers and seed at an early stage, some specimens of the former retain both flower and seed over a long period. The influence here would seem to be $B$. marginata as it is to the south of the nearby Mallacoota Aerodrome on the margin of Melaleuca armillaris stands. 
Table 1. Comparison between B. croajingolensis, B. marginata, B. paludosa and B. integrifolia.

Character

Habit

Size

Shape

Mostly small

Spreading

Small

Branchlets

Indumentum

Colour

\section{Leaves}

Shape

Margin

Apex

Phyllotaxis

Node to

Node

length

Adaxial

surface

Abaxial

surface

Margins

Length

Width

\section{Conflorescence}

$\begin{array}{ll}\text { Shape } & \text { Cylindrical } \\ \text { Position } & \begin{array}{l}\text { Terminal on } \\ \text { branchlets and } \\ \text { older wood, often } \\ \text { subtended by } \\ \text { branchlets }\end{array}\end{array}$

Glabrous or initially Villous, often pubescent, soon glabrescent

Red or yellow

Green

Narrowly obovate

Seldom irregularly notched towards apex

Obtuse, shortly apiculate or emarginate

Verticillate, sub-verticillate or scattered

Short

Glabrous, shiny

White woolly but with main nerves and reticulum evident
Truncate, often emarginate

Alternate, scattered

Short

Hirsute dull, becoming glabrous

White woolly, nerves not visible reticulum evident
B paludosa

B integrifolia

Small to medium

Spreading

Medium to tall

Upright

Glabrous

Red or yellow

Green, often becoming yellow or red

Broadly or narrowly obovate

Entire in adult phase

Obtuse

Obtuse

Verticillate

Verticillate

Widely spaced

Mostly widely spaced

Glabrous, glossy

Appearing green with prominent, main nerves and reticulum, with white woolly indumentum in reticulum pits, occasionally encroaching on the reticulum

Recurved to

Recurved

Recurved revolute

12-42 mm

40-130 mm

26-100 mm

3-9 $\mathrm{mm}$

$15-35 \mathrm{~mm}$

$7-20 \mathrm{~mm}$

\section{Cylindrical}

Terminal or more

often on

older wood
Cylindrical

Terminal on or older wood and often subtended by branchlets 


\section{Character}

Height

Width at

flowering

\section{Flowers}

$\begin{array}{ll}\begin{array}{ll}\text { Arrangement } \\ \text { on rachis }\end{array} & \text { Open } \\ \text { Colour in bud } & \text { Yellow with a } \\ & \begin{array}{l}\text { grey brown, grey } \\ \text { green or golden } \\ \text { pubescence }\end{array} \\ \text { Sequence } & \text { Basipetalous }\end{array}$

Style

Posture prior

to anthesis

Colour

Length

\section{Infructescence}

Height

Width

Seed

$\begin{array}{ll}\text { Shape } & \text { Obovate cuneate } \\ \text { Length } & 8-10 \mathrm{~mm} \\ \text { Width } & 3-3.5 \mathrm{~mm} \\ \text { Wing Length } & 11-12 \mathrm{~mm} \\ \text { Wing Width } & 12-13 \mathrm{~mm}\end{array}$

\section{B marginata}

40-70 mm

$45-47 \mathrm{~mm}$

Close

Lemon with grey pubescence

Acropetalous

Bowed

Straight or

bowed

Yellow

15-26 mm

90-120 mm

35-38 mm

Pale yellow

20-31 mm

45-50 mm

28-30 mm
B paludosa

70-130 mm

45-50 mm

Open

Yellow with

golden brown

pubescence

Acropetalous

Straight or slightly bowed

Falcate cuneate

5-7 mm

$3 \mathrm{~mm}$

7-9 mm

8-9 mm
Yellow

17-20 mm

75-110 mm

40-45 mm

Obovate falcate

$7.5-8 \mathrm{~mm}$

$3.5 \mathrm{~mm}$

9-10 mm

10-12 mm

\section{B integrifolia}

110-150 mm

60-70 mm

Close

Yellow with

a white

pubescence

Acropetalous

Bowed

Pale yellow

27-32 mm

$75-85 \mathrm{~mm}$

28-32 mm

Narrowly obovate cuneate

8-9 mm

3.5-4 mm

$10-11 \mathrm{~mm}$

$6-8 \mathrm{~mm}$

All colour coding 1986 Edition RHS Swatch.

Unfortunately, in many instances specimens of these swarms have been assigned indiscriminately to either $B$. integrifolia or B. marginata. This suggests that further detailed study of all Banksia populations within this region is needed. The anomalous habitat of $B$. integrifolia on the lower middle reaches of the Betka River, where it grows as a rheophytic chasmophyte, warrants investigation. Banksia integrifolia is also recorded from the lower reaches of the Genoa River gorge many kilometres upstream from the coast.

\section{Acknowledgments}

Gippsland has been a botanical 'happy hunting ground' for the authors for more than thirty years, and certain people have been consistent supporters or critical reviewers of papers by one of us (Molyneux) on numerous occasions. David Cameron, Victorian Department of Sustainability and Environment, has contributed greatly to this paper with discussions on an appropriate epithet and common name, the paper's structure, and its editing. Neville Walsh (National Herbarium of Victoria - MEL) assisted with the structure of the paper with a range of modifications and supplied the Latin diagnosis. 
Peter Weston (National Herbarium of New South Wales) made several worthwhile suggestions on clarifying the taxon, while Bob Semmens (Mallacoota) made several seasonal collections and observations for us. Thanks also to Lyn Bell (Head Ranger) for access to Nadgee Nature Reserve and for driving one of us (Molyneux) to Impressa Moor, and to Jackie Miles for her observations and assistance with field work on that day. The authors also thank the staff of MEL for access to collections and to the library.

In addition, we wish to thank Grattan Mullett, Co-ordinator Krowathunkooloong Keeping Place, Bairnsdale, Victoria, Graham Thorpe, Chairperson of the Gurnai/ Kurnai Instructing Committee and the Bidawal People for their support regarding the use of the name croajingolensis as the epithet for this new taxon.

\section{References}

Harden GJ (2002) Banksia. Pp. 82-86 in Harden GJ (ed.) Flora of New South Wales, revised edition, vol. 2. (New South Wales University Press: Kensington)

IUCN (2001) IUCN Red List Categories: Version 3.1. Prepared by the IUCN Species Survival Commission. (IUCN: Gland \& Cambridge)

Jeanes JA (1996) Banksia. Pp. 882-887 in Walsh NG \& Entwisle TJ (eds) Flora of Victoria, vol. 3. (Inkata Press: Melbourne)

Johnson LAS \& Hill KD (1990) New taxa and combinations in Eucalyptus and Angophora. Telopea 4: 37-108.

Manuscript received 15 January 2007, accepted 08 March 2007 